\title{
Development of a village-level livelihood monitoring tool: A case-study in Viengkham District, Lao PDR
}

\author{
${ }^{1}$ Royal Roads University, Victoria, Canada \\ ${ }^{2}$ CIFOR-RRU, Lao PDR \\ ${ }^{3} I R D-C I F O R$, Vientiane \\ ${ }^{4}$ CIRAD-CIFOR, Bogor Indonesia
}

B. BELCHER ${ }^{1}$, F. BASTIDE ${ }^{2}$, J.C. CASTELLA ${ }^{3}$ and M. BOISSIERE ${ }^{4}$

Email: brian.belcher@royalroads.ca

\begin{abstract}
SUMMARY
Effective monitoring is a fundamental requirement for adaptive management. The need for better tools for monitoring livelihoods is particularly acute. A simple indicators-based livelihoods monitoring tool to be used at the village scale was developed and tested. Participatory methods were used to elicit local perceptions and aspirations about development and conservation. That information was used to develop a prototype set of indicators, organized using the Sustainable Livelihoods Framework. Data were collected for the indicators in six villages to calibrate and test the tool. Indicators of financial and physical capital worked well. Social capital and natural capital were more difficult to capture with low-cost indicators. Most of the indicators are applicable in rural areas of the district and beyond. Despite some shortcomings, the tool shows good potential as a way to focus attention on key aspects of rural development and as a way to inform and facilitate discussion and negotiation between communities and other stakeholders.
\end{abstract}

KEYWORDS: participatory monitoring, livelihood indicators, adaptive management, conservation and development, Lao PDR

Mise au point d'un outil de suivi-évaluation des moyens de subsistance à l'échelle d'un village. Etude de cas dans le district de Viengkham, Laos

\author{
B. BELCHER, F. BASTIDE, J.C. CASTELLA et M. BOISSIERE
}

L'utilisation d'une méthode appropriée de suivi-évaluation est indispensable aux processus de gestion adaptative. Pour cela, des outils plus performants de suivi-évaluation des moyens de subsistance sont requis. Un outil basé sur des indicateurs simples de moyens de subsistance a été développé et testé à l'échelle du village. Des méthodes participatives intègrant les perceptions et aspirations locales en matière de développement et de conservation ont été utilisées pour développer un jeux d'indicateurs types, à partir de l'approche Sustainable Livelihoods Framework. Les données relatives à ces indicateurs ont été collectées dans six villages pour calibrer et tester l'outil. Les indicateurs de capitaux financiers et physiques ont donné des résultats satisfaisants. Les capitaux sociaux et naturels ont été plus difficiles à appréhender. La plupart des indicateurs sont applicables en milieu rural à l'échelle du district et au delà. Malgré quelques limitations, l'outil montre un bon potentiel pour mettre en perspective des aspects clés du développement rural, et pour informer et faciliter les discussions et négociations entre les différents acteurs.

Desarrollo de una herramienta de monitoreo de medios de subsistencia a escala de comunidad: un estudio de caso del distrito de Viengkham, RDP Lao

\section{B. BELCHER, F. BASTIDE, J.C. CASTELLA y M. BOISSIERE}

Un monitoreo efectivo es un requisito fundamental para una gestión adaptativa. En particular, la necesidad de mejores herramientas para el monitoreo de medios de subsistencia es manifiesta. En este estudio se ha desarrollado y probado una herramienta sencilla de monitoreo de medios de subsistencia basada en indicadores, para ser utilizada a escala de comunidad. Se emplearon métodos participativos para descubrir las percepciones y ambiciones locales en cuanto a desarrollo y conservación. La información obtenida fue utilizada para desarrollar el prototipo de un juego de indicadores, clasificados de acuerdo al Marco de Medios de Subsistencia Sostenibles. Para calibrar y probar la herramienta se recolectaron datos de seis comunidades para ser empleados en los indicadores. Los indicadores del capital financiero y físico funcionaron bien. El capital social y el natural fueron más difíciles de capturar por medio de indicadores de bajo costo. La mayoría de indicadores son aplicables a áreas rurales de este distrito y sus alrededores. A pesar de sus deficiencias, esta herramienta muestra un gran potencial como una manera de llamar la atención sobre aspectos claves del desarrollo rural, y como un modo de informar y facilitar el diálogo y la negociación entre comunidades y otras partes interesadas. 


\section{INTRODUCTION}

Conservation-oriented policies, programs and projects are changing in important ways. Interventions increasingly operate at large spatial scales and deal with complex land cover mosaics. They commonly have explicit objectives to improve livelihoods or alleviate poverty along with their conservation objectives. There is also much more emphasis on participatory approaches that involve local stakeholders in problem definition, project design and implementation. Efforts to combine conservation and development objectives are increasingly seen as experimental, complex and uncertain processes in which the participation of those expected to benefit is essential to success (Stringer et al. 2006). However, the tools and approaches for doing this are still not well developed. Notably, there is a need for better and more interactive ways to measure and monitor the impacts of conservation and development programs and projects (Danielsen et al. 2005). Effective monitoring is a fundamental requirement in any effort to do "adaptive management" (Lee 1993, Senge 2006). Project managers and other stakeholders require reliable information about what is changing and how it is changing, so they can steer interventions effectively, and adapt to unexpected developments.

Monitoring tools should also support impact assessment to help meet the growing criticism about the lack of evidence of impacts. For example, as Brooks et al. (2006) found in their work on conservation and development outcomes, evaluation methods still focus primarily on the state of species or ecosystems, or simply on project deliverables. Their attempt to evaluate conservation and development projects concluded that there was insufficient data collected by projects to know if they have had any impact on target landscapes and livelihoods. This is remarkable considering the importance of the task, and the large collective investment that has been made in project implementation.

The widespread acknowledgement of the importance of poverty alleviation is encouraging and many agencies, including national forest agencies and international conservation organizations, now include explicit poverty alleviation objectives in their projects. The very definitions of "poverty" and "livelihoods" have become broader and more sophisticated. Simple measures of income and assets have been replaced by a welcome recognition of the many non-financial aspects of livelihoods (Sen 1999). The Sustainable Livelihoods Approach (SLA) (Carney et al. 1999, Bebbington 1999, Ellis 2000) provides a useful conceptual framework. Ellis (2000) defines livelihood as comprising: “... the assets (natural, physical, human, financial and social capital), the activities, and the access to these (mediated by institutional and social relations) that together determine the living gained by the individual or household (10)."

Considerable attention and effort have been devoted to develop criteria and indicators of sustainable forest management, though most have focused primarily on ecological processes and trends (Beckley 2000, Fraser et al. 2006). When social indicators are included, they have often focused on sustainability of the forest as the desired end, and not on the sustainability or well-being of communities (Harshaw et al. 2007, Evans and Gariguata 2008). While progress has been made with conservation impact measurement, advances in measuring livelihoods have been more limited (Wells and McShane 2004).

The literature on Monitoring and Evaluation (M\&E) increasingly deals with formative approaches, where the emphasis is on learning and adapting. And the M\&E literature as well as the growing literature on Criteria and Indicators (C\&I) have seen a push for more participatory, "bottom up" indicators development as a way to capture the richness in definitions of sustainability that cannot be appreciated through "top-down" structures (Sherry et al. 2005) and for greater relevance to community goals and aspirations (Burley 2001, Beckley et al. 2002). Local indicator development is still needed though to capture the richness in the definitions of sustainability that cannot be appreciated through top-down structures, especially to take into account traditional knowledge and local concerns and desires (Natcher and Hickey 2002, Sherry et al. 2005). There are promising ideas and insights to build upon such as The Livelihood Asset Status Tracking (LAST) tool (Bond and Mukherjee 2002, Bond et al. 2005) and the Landscape Outcome Assessment Methodology (LOAM) (Sayer et al. 2006, Aldrich and Sayer 2007) that uses participatory modeling of landscape-scale change to engage stakeholders to think through project outcomes at a landscape scale. Endamana et al (2010) used jointlydeveloped qualitative indicators representing the interests of a range of stakeholders, defined within the sustainable livelihoods framework.

The application of participatory methods promises not only to make the parameters measured more relevant, but to change the way interventions are designed and implemented. Conservation organisations have often made unwarranted assumptions about what is desired by, or good for, local people. Participatory M\&E can help empower local stakeholders to contribute to defining project objectives and to monitor and evaluate the impacts of interventions (Sayer et al. 2006). A good monitoring tool can facilitate engagement, empowerment, negotiations and the incorporation of local values in program and project design and implementation. Effective, low-cost tools are needed in forest management projects, including the new wave of REDD+ projects, community forest development, conservation projects, and other projects that aim to engage and improve the livelihoods of local people.

To help meet this need, a simple indicators-based livelihoods monitoring tool was developed and tested. Participatory methods were used to elicit local perceptions and aspirations about local development and conservation. That information, and our own understanding of the local context and development processes, was used to develop a prototype set of indicators. Data for the indicators were then collected in six villages and used to calibrate and test the indicators. The project also helped to initiate a process of annual data collection and comparison among these villages. This paper describes the approach and the lessons learned. 


\section{STUDY LOCATION}

The study was done in Viengkham District of Luang Prabang Province, in the northern part of the Lao People's Democratic Republic (Fig. 1). It is one of the 47 poorest districts in the country and has been identified as a priority for a povertyfocused planning process at the district level (GoL 2003). It is also a pilot site for testing the Participatory Land Use Planning (PLUP) approach, which aims to engage village communities in planning the management of their own landscapes (MAF-NLMA 2009, Bourgoin et al. 2012). The district is mountainous, rural and the most forested in the province. It includes the country's second largest National Park, Nam-Et Phou Loey, covering almost 595000 ha of mountainous terrain and with high conservation value. As such, Viengkham is a target district for externally funded projects focusing both on development and on conservation.
The research associated with the Landscape Mosaics (LM) project of the National Agriculture and Forestry research Institute (NAFRI) and the District Agriculture and Forestry Office (DAFO, Viengkham) in partnership with the Center for International Forestry Research (CIFOR). Six study villages were selected from one "kumban" or village cluster: Bouami (BM), Dongkeo (DK), Houaykon (HK), Muongmuay (MM), Paklao (PK) and Vangkham (VK). These villages represent a range of conditions typical of the area, with elevations from 600 MASL to over 1000 MASL, a mix of agricultural and forest land uses, and a range of remoteness from road access and proximity to the NPA (Castella et al. 2011). The people living in the study villages are primarily Lao Loum and Khamu ethnically. Upland rice, the main agricultural product and staple food, is largely consumed by its producers. Livestock (cattle, pigs, goats) is the main source of cash income. Supplementary income comes from Non

FIGURE 1 Location of research villages and case study landscape

\section{Legend}

- Province capital

- Target villages

Main roads

Case study landscape

National Protected Area
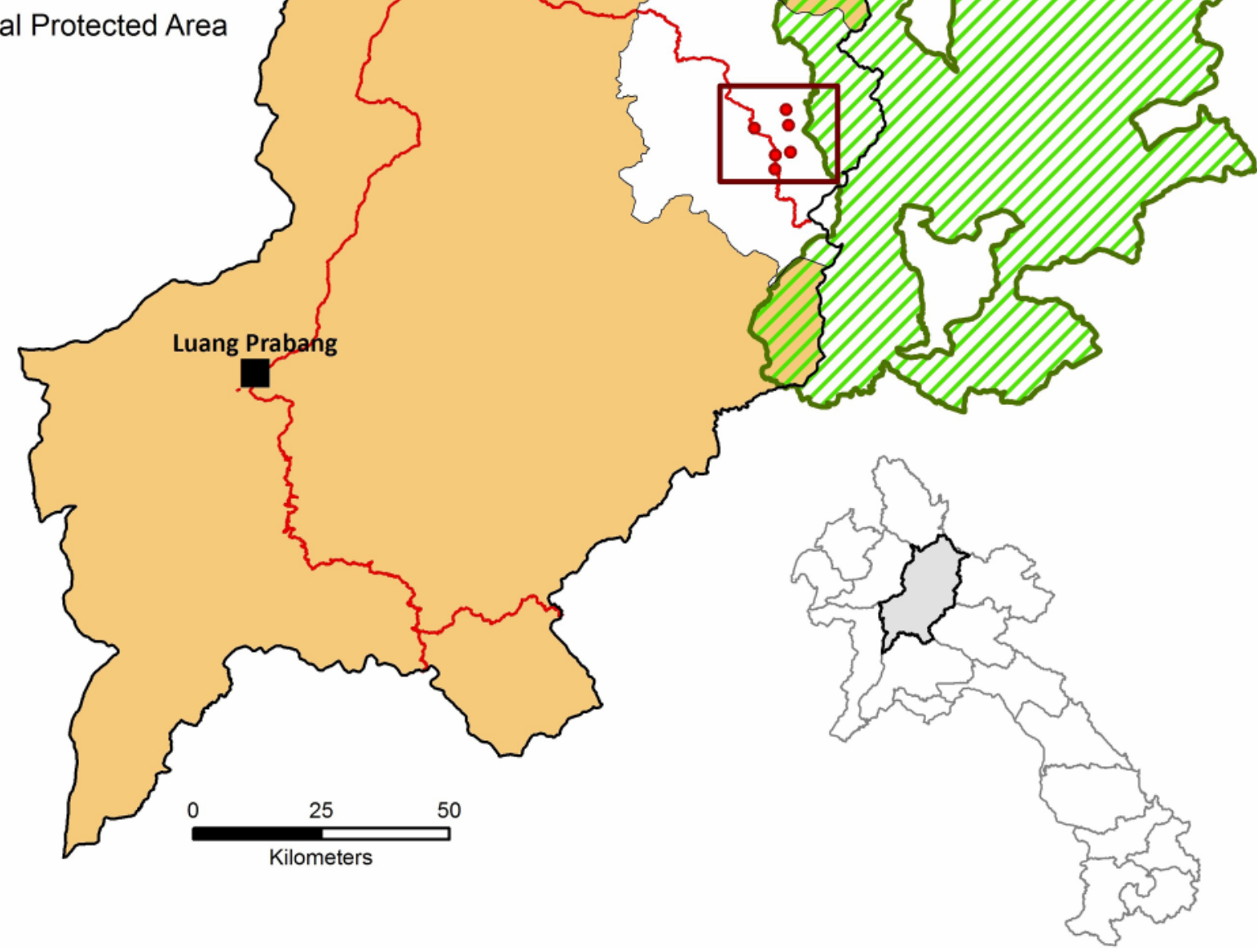
Timber Forest Products (NTFP) harvesting for subsistence use and for sale. Three villages (DK, MM, VK) are located along national route one, three are remote from the road (PL, BM, HK) and share boundaries with the National Park. The rules of the park, established in 1993, prohibit hunting and gathering within park boundaries. This prohibition, enforced since 2004 by the NPA and district authorities with the support of the Wildlife Conservation Society (Johnson 2011), has affected subsistence patterns of villages sharing boundaries with the park.

\section{DEVELOPING A LIVELIHOODS MONITORING TOOL}

The aim was to develop a livelihoods monitoring tool based on simple, low-cost data, to give a general picture of livelihoods status and change at the village scale. The aim was to accurately reflect livelihoods, measured in terms that are relevant and comprehensible to local stakeholders. It was intended to track progress in a given village over time and to compare and contrast status and changes across villages.

With periodic data collection (e.g. annually) it would be possible to see trends in individual villages over time, and even to see differential changes in the various elements of livelihoods (the "capital assets"). It was intended that the tool would be useful to government and to conservation and development organizations to be able to monitor livelihoods impacts of their programs. As, or more important, the tool should be valuable for community members and village leaders, as an objective and comparable measure of development for their own information, to monitor their own progress and to inform their negotiations with external agencies.

\section{Defining what to monitor}

To determine what to measure and/or monitor, it is necessary to anticipate what kinds of changes are likely and how those changes will translate into livelihoods benefits or costs. As described above, there are many forces at play that are changing the way people in these villages work and live. It is a dynamic and complex socio-economic environment, with trends such as: reduced area for shifting cultivation, increased cash cropping, improved transportation and communications infrastructure, increased off-farm income opportunities, reduced access by villagers to resources and land in protected areas, development projects that aim to improve efficiency and productivity of livestock husbandry, increased private and public investment in productive assets, improved access and investment in education and health care, and, increased investment in conservation and enforcement.

Conservation and development policies have had a strong influence on the landscape and on livelihoods. Agriculture and forest are increasingly separated as the traditional swidden cultivation system is displaced. The forest cover is regenerating in protected areas while increased concentrations of people along roads in the western part of the study area are increasing the cropping intensity on limited agricultural land, leading to a spiral of land degradation and poverty (Castella et al. 2011, Hett et al. 2011).

\section{Assessing local knowledge and aspirations}

The project undertook several participatory processes in each village to engage community members in discussions about current conditions, trends and likely implications, and about their own expectations, aspirations and concerns. Specifically:

- Participatory Mapping to facilitate group discussions of spatial arrangements and resource management and use (Fitriana 2008, Boucard et al. 2010, Boissière et al. In press)

- Focus Group Discussions to assess perspectives by social position, gender and age (Colfer and Pfund 2010, Boucard et al. 2010)

- Multidisciplinary Landscape Assessment (MLA) to assess local values of natural resources (Pfund et al. 2011, Sheil et al. 2002)

- Visioning exercises, to anticipate future developments (Watts et al. 2011)

- Participatory photography workshops to understand and discuss local perspectives on development and resources (Belcher and Roberts In press)

Also, workshops were held in February and July 2009 that included full-day sessions on monitoring. Mixed groups of stakeholders discussed and suggested potential indicators and their definition.

These exercises identified key themes, concerns and hopes, relating to: agriculture and livestock production and management, infrastructure (roads, water and sanitation, energy), education, health, housing and other modern amenities, and, nature and natural resources (Belcher and Roberts In press).

\section{Developing livelihoods indicators}

The village scale was seen as the most appropriate scale for monitoring. Natural resources are managed at the village level, many key determinants of livelihoods (e.g. road access, school quality, electricity service) operate at the village scale, and project interventions often target villages. Collecting, analyzing and comparing data at the household scale is more precise but much more costly. The main disadvantage of monitoring at the village scale is that it can disguise inequality within the village. There are several indicators that could be used as indicators of inequality (e.g. house quality, toilets, water access, grade 5 completion).

The set of indicators, collectively, should represent overall livelihoods status and change. The project followed Bond and Mukherjee (2002) and Aldrich and Sayer (2007) in using the "Sustainable Livelihoods Framework" (Ellis 2000) to help define and organize indicators. Five to six indicators were developed in each category of livelihood assets.

Natural Capital refers to the biological products and environmental services available to people from forest, land and rivers. Agricultural resources are the most important livelihood asset, and rice is the most important staple food. A 
measure of rice sufficiency was included as a key indicator, and a second indicator reflects drinking water availability. The LM project made a concerted effort to identify priority natural resources using MLA (Pfund et al. 2011) and developed a separate participatory natural resources monitoring system (Boucard et al. 2010, Boissière et al. In press). Building on this, village fish, broomgrass (Thysanolaena latifolia) and peuak meuak (Boehmeria malabarica) production were selected as indicators that reflect the quality and availability of natural resources for people's use.

Physical Capital (or Built Capital) is human-made capital - shelter, vehicles and transportation infrastructure, agricultural machinery, communications facilities, and so on. Measures of quality of road access (a priority to local people and government officials alike), piped water access, irrigated and rain fed rice land and electricity available to households were included. These indicators all reflect investment in productive capacity and their quality and availability are a good reflection of living standards in a village.

Human Capital refers to people's skills, knowledge and information, health and the ability to work. It is important for enjoying life and for productivity. Infant Mortality Rate was used as a measure of health. This is a widely-used indicator of well-being, defined in terms that can be compared internationally. Several indicators of education success were proposed, to take into account the difficult conditions, with substantial barriers to advancing beyond grade 3 (the highest level that is available in all villages). Indicators were included to measure numbers of eligible students who complete grade 3 and who go on to secondary school, as well as the gender representation in those groups. Secondary school attendance requires a higher level of commitment and wealth. People highly value education and this indicator is expected to rise as livelihoods improve.

Financial Capital encompasses savings, credit, remittances and other cash-based assets. This is the most common (and easiest) measure of welfare. People value housing quality and transportation. Indicators were developed based on motorcycle and car ownership, home building materials, electrical and sewage services and livestock ownership. These indicators reflect the availability of disposable income and investment in assets that improve livelihood options (mobility, housing, sanitation).

Social Capital includes networks, groups, trust and access to institutions. It is the most difficult aspect of livelihoods to measure, and the most difficult to devise useful indicators for. Some measure of cooperation, collective effort and "harmony" within the community is needed. Cooperative labor is commonly used in the area to build houses, repair roofs, and also to build and maintain public works such as roads and community buildings. A measure of time invested in cooperative labor was used as an indicator of social capital. Several indicators of gender equity, in terms of women's representation on village committees, were also included. The gender variables were not identified in the participatory process but were incorporated as a way to reflect diversity and engagement at the local level, and to reflect values that are increasingly included in donor-funded projects.
The boundaries between these asset classes are not clear. It is an artificial classification of elements of livelihoods and it is a useful way to structure our thinking, but there will always been some grey areas. The key is to be clear about what the indicator is measuring. For example, "School building" was suggested as an indicator of education during a workshop. Having a school building in a village indicates that the village had access to the resources necessary for its construction and maintenance. This is a good example of physical capital, but it is not a good indicator because changes are not incremental, it is likely that the indicator will not change over the relevant time scale. More importantly, it is not useful as an indicator of education because it is not sufficient. There may be a good schoolhouse, but no teacher, or no money for school fees, or no time for kids to attend. A good indicator of education should measure actual educational attainment. Grade levels were used as a proxy.

The indicators are not intended to stand alone and the data are not supposed to be used for detailed individual analysis. Rather, they are intended to be used as a set that collectively provides a snapshot of livelihoods status at the village scale and that, over time, will provide an indication of trends.

Indicators must be sensitive to actual changes in livelihoods status. They should be expected to change incrementally, with strong correlation to actual changes in livelihoods status. For example, in the "Financial Assets" category, number of motorcycles in a village was used. It is expected (based on our discussions and observations) that most families would like to own a motorcycle. However, the cost of ownership is high enough that not everyone will be able to purchase one at the same time. Cars/trucks were also included, but the threshold for ownership is higher so it will be less sensitive as an indicator. An item with lower value (e.g. radio) that can quickly saturate the market is less sensitive and less useful as an indicator.

Indicators were defined as ratios (per capita or percentage) and presented in percentage terms to make them comparable over time and across villages. Appropriate ranges were determined for each indicator based on current conditions in the study villages and likely changes in those values in the future. This was straightforward for some variables: there can be a minimum of 0 and a maximum of $100 \%$ of houses in a certain category, or a grade completion rate, or anything else measured in percentage. Other variables required more judgment: reasonable maxima for variables such as the number of motorcycles, or cattle or water taps per capita were estimated. For these kinds of variables, a value at the low end of the range was set to equal 0 and the maximum value in the range was set to equal 100 .

Some indicators are more informative or important than others and that needs to be reflected in assigned weights. This is a subjective exercise. Local people were consulted during successive workshops and the researchers used their own judgment. A maximum weight of 3 was assigned to "infant mortality" and to "rice insufficiency". These were identified by local people as key indicators of welfare. Water insufficiency and a measure of cooperative labor were each assigned weights of 2 . Values of less than 1 were assigned where 
several indicators represent similar attributes. For example, indicators of gender representation on 5 different village committees were each assigned a weight of 0.2 , for a total weight of 1 . Most variables were assigned a default weight of 1 .

Finally, the value of each category of capital is expressed in percentage terms. In other words, while total "Financial capital" indicators have a maximum value of 550 and "Physical Capital set has a maximum value of 700, each category has a maximum value of 100 .

The prototype indicators are shown in Tab. 1. The table shows the asset categories, the data requirements, the formulae and the weights for each indicator.

\section{Data collection and analysis}

The first round of data was collected in January 2011. Education data were not available at the village level, so appropriate data from the 2005 census were used for the trial. Current ranges in the values for each indicator were examined to help calibrate the tool, assign weights and develop formulae as described above. Weighted indicator values were calculated and displayed as radar diagrams that show current overall livelihoods status by village (Fig. 2) and by capital type (Fig. 3)

In subsequent years it will be possible to also show change over time.

The indicators were validated by comparing the relative livelihoods status of villages as shown by this method with participatory village assessments organized by our team with both a group of district officers and village leaders of the target village cluster. Qualitative classifications by district officers and by village leaders both ranked villages in the following order, from more to less well-off: $\mathrm{MM}>\mathrm{VK}>$ $\mathrm{DK}>\mathrm{PL}>\mathrm{BM}>\mathrm{HK}$. Our ranking, using all categories of indicators, is: $\mathrm{VK}>\mathrm{MM}>\mathrm{HK}>\mathrm{PL}>\mathrm{BM}>\mathrm{DK}$. The differences between these rankings reflect the high weight given by local authorities to financial and physical capital, which are highest in MM and VK. HK ranks relatively high in our classification because it scored high in natural capital and because it has many medium class (category 2) houses and small-scale private electricity generation capacity.

Neither ranking is necessarily "correct". However, the tool encourages and facilitates an explicit examination of the criteria for assessing livelihoods status and change. The process of developing the tool engages stakeholders in thinking about and defining the elements of livelihoods, and using it for monitoring is intended to provide a platform for assessing progress and adapting accordingly. Ideally, it would also encourage ongoing dialogue and engagement about livelihoods and local development.

\section{Implementation/institutionalization}

The intention is to provide a tool that will be useful and used. The project maintained close relations with District officials to inform and to incorporate their ideas in the design of the tool. All field missions included visits to the District Agriculture and Forestry Office (DAFO) at arrival and departure to explain the activities, and a DAFO staff person systematically joined the team in the villages. As discussed above, community members, government and project staff were involved in a set of exercises designed to elicit opinions and discussion and to contribute to the design of the livelihoods monitoring tool. There is some risk that the having government officials present can have a negative impact on participation by others, or on accuracy of the information they provide, especially in a hierarchical culture such as in Laos. This needs to be managed through active facilitation and data triangulation.

The District government collects village statistics annually. They agreed to make those data available for use with this monitoring tool. Furthermore, they agreed to add questions in future rounds so that those data will be sufficient for the annual monitoring. This will make it possible to track changes in these villages over time and to apply the tool to all villages in the District. However, in order to be useful as an engagement tool and as a means of providing relevant feedback to stakeholders in communities, government and projects, it needs to be integrated with ongoing activities.

Ideally, the communities and the district government would adopt a tool of this kind to monitor livelihoods change and use it as a basis for dialogue about local development to help guide policy and project implementation. This has not happened yet because the current tool has just been developed and only a single year of data is available. It would need two or three years to fully test the tool to be able to demonstrate its potential. As one way to encourage familiarity and uptake by the villages, a "Kumban Day" was organized in December 2010, a festival in which the villages in the Kumban came together for celebrations and sports, handicrafts and agricultural competitions. It also included a presentation of the project's work. The idea was to institutionalize Kumban Day as an annual event, to facilitate discussion or even competition in the realm of "village development" or "livelihoods improvement" as a way to raise interest and to help focus attention on priority issues. However, the project that supported the development of the tool has ended and there is no direct support available to promote further implementation. Government officials respond to directives from higher levels and to opportunities provided by externally funded projects. It is likely that some incentives would be required to convince officials to adopt the approach (Poulsen and Luanglath 2005, Singh 2008).

\section{CONCLUSIONS}

This experience demonstrates that it is feasible to develop a light, low-cost tool to monitor livelihoods status and change at the village scale. Both the process of developing the tool and the results of the monitoring help engage local stakeholders in planning, evaluating and adaptively-managing conservation and development activities. An initial external investment is necessary to develop and promote the approach and to facilitate community engagement. This can be done during the early stages of new government programs or donor-supported projects. 
TABLE 1 Indicator data and formulae

\begin{tabular}{|c|c|c|c|c|c|}
\hline Asset & Data & Indicator & Range & Weight & Formula \\
\hline General & Village population $(\mathrm{A})$ & Village population & & & \\
\hline General & $\begin{array}{l}\text { Number of Families } \\
\text { (B) }\end{array}$ & Number of Families & & & \\
\hline General & Number of houses (C) & Number of HH/houses & & & \\
\hline General & Village Labor force & Village Labor force & & & \\
\hline Financial & No of houses Cat $2^{1}$ & $\%$ of houses in Category 2 & Range 0:100\% & 0.5 & {$[\mathrm{Data} / \mathrm{C}] * 1 * 0.5 * 100$} \\
\hline Financial & No of houses Cat 3 & $\%$ of houses in Category 3 & Range 0:100\% & 1.0 & {$[$ Data/C]*1* $1 * 100$} \\
\hline Financial & No of car/truck & Number of big vehicle / capita & Range 0:0.1 & 0.5 & {$[$ Data/A]* $1000 * 0.5$} \\
\hline Financial & No of motorbikes & Number of motorbikes / capita & Range 0:0.5 & 1.0 & {$[$ Data/A]*200*1 } \\
\hline Financial & $\begin{array}{l}\text { No houses with } \\
\text { electricity }{ }^{2}\end{array}$ & $\begin{array}{l}\% \text { of houses with electricity } \\
\text { supply }\end{array}$ & Range 0:100 & 1.0 & {$[\mathrm{Data} / \mathrm{C}] * 100 * 1 * 1$} \\
\hline Financial & $\begin{array}{l}\text { No private toilets in } \\
\text { village }\end{array}$ & Number of toilets / Capita & Range 0:0.25 & 0.5 & {$[$ Data/A $] * 400 * 0.5$} \\
\hline Financial & No. of cattle ${ }^{3}$ & Number of cattle / capita & Range 0:2 & 1.0 & {$[$ Data/A $] * 50 * 1$} \\
\hline Physical & $\begin{array}{l}\text { Access by car all the } \\
\text { year }^{4}\end{array}$ & Car access & Range 0:1 & 1.0 & Data*100*1 \\
\hline Physical & $\begin{array}{l}\text { Access by motorbike } \\
\text { all year }\end{array}$ & Motorbike access & Range 0:25 & 0.5 & Data* $100 * 0.5$ \\
\hline Physical & $\begin{array}{l}\text { No of houses with } \\
\text { private water tap }\end{array}$ & Number of private tap / Capita & Range $0: 0.25$ & 0.5 & {$[$ Data/A $] * 400 * 0.5$} \\
\hline Physical & $\begin{array}{l}\text { Area (ha) rain-fed rice } \\
\text { field }\end{array}$ & Area (ha) rain-fed land /cap & Range 0:0.20 & 0.5 & {$[$ Data/A $] * 500 * 0.5$} \\
\hline Physical & $\begin{array}{l}\text { Area (ha)irrigated rice } \\
\text { field }\end{array}$ & $\begin{array}{l}\text { Area (ha) irrigated paddy land / } \\
\text { cap }\end{array}$ & Range 0:0.20 & 0.5 & {$[$ Data/A $] * 500 * 0.5$} \\
\hline Physical & $\begin{array}{l}\text { No houses with } \\
\text { electricity from grid }\end{array}$ & $\%$ of houseswith grid electricity & Range 0:100 & 1.0 & {$[$ Data/C $] * 100 * 1 * 1$} \\
\hline Natural & $\begin{array}{l}\text { No of rice insufficient } \\
{ }^{5} \text { families }\end{array}$ & $\begin{array}{l}\% \text { of families that are rice } \\
\text { insufficient }\end{array}$ & Range 0:100 & 3.0 & {$[\mathrm{Data} / \mathrm{B}] * 100 * 1 * 3$} \\
\hline Natural & $\begin{array}{l}\text { No of months piped } \\
\text { water insufficient }{ }^{6}\end{array}$ & $\begin{array}{l}\text { Inverse of No of months piped } \\
\text { water insufficient }\end{array}$ & Range 0:12 & 2.0 & $(12-[$ Data $]) * 8.3333 * 2$ \\
\hline Natural & $\begin{array}{l}\text { Total Peuak Meuak } \\
\text { harvest in village }(\mathrm{Kg})\end{array}$ & Peuak Meuak harvest $(\mathrm{kg}) / \mathrm{cap}$ & Range 0:20 & 0.5 & {$[$ Data $/ \mathrm{A}] * 5 * 0.5$} \\
\hline Natural & $\begin{array}{l}\text { Total Broom Grass } \\
\text { harvest in village }(\mathrm{Kg})\end{array}$ & Broom Grass harvest (kg)/cap & Range 0:20 & 0.5 & {$[\mathrm{Data} / \mathrm{A}] * 5 * 0.5$} \\
\hline Natural & $\begin{array}{l}\text { Total fish harvest in } \\
\text { village }(\mathrm{Kg})\end{array}$ & Fish harvested $(\mathrm{kg}) / \mathrm{cap}$ & Range 0:50 & 1.0 & {$[$ Data/A $] * 2 * 1$} \\
\hline \multirow[t]{2}{*}{ Human } & $\begin{array}{l}\text { No of infant death } \\
(<1 \mathrm{yr})(\mathrm{D})\end{array}$ & \multirow[t]{2}{*}{ Infant Mortality Rate } & \multirow[t]{2}{*}{ Range 0:200 } & \multirow[t]{2}{*}{3.0} & \multirow[t]{2}{*}{$\begin{array}{l}(200-[\text { Data D/Data } \\
\mathrm{E}] * 1000) * 0.5 * 3\end{array}$} \\
\hline & No of live births (E) & & & & \\
\hline
\end{tabular}

1 Cat $1:$ Walls \& roof made of bamboo

Cat 2: Walls made of wood \& metal or fibreglass roof

Cat 3: Walls made of concrete, metal roof

2 Electricity - only primary connection

3 Cows and buffalos

${ }^{4}$ Car and Motorbike access: $\mathrm{Y}=1 \mathrm{~N}=0$

5 Rice insufficiency $<350 \mathrm{~kg} / \mathrm{yr} / \mathrm{cap}$

6 Water shortage $<20$ L/Day/Cap 
TABLE 1 Continued

\begin{tabular}{|c|c|c|c|c|c|c|}
\hline \multicolumn{2}{|c|}{ Asset } & Data & Indicator & Range & Weight & Formula \\
\hline \multirow{2}{*}{\multicolumn{2}{|c|}{ Human $^{7}$}} & $\begin{array}{l}\text { No of } 6 \text { year old } \\
\text { children }\end{array}$ & \multirow[t]{2}{*}{$\begin{array}{l}\text { Proportion of } 6 \text { year olds in } \\
\text { school }\end{array}$} & \multirow[t]{2}{*}{ Range 0:100 } & \multirow[t]{2}{*}{0.3} & \multirow[t]{2}{*}{$\begin{array}{l}{[\text { Data } \mathrm{H} / \mathrm{Data} \mathrm{F}] *} \\
100 * 1 * 0.3\end{array}$} \\
\hline & & $\begin{array}{l}\text { School attendance } \\
\text { among } 6 \text { year old } \\
\text { children }\end{array}$ & & & & \\
\hline \multirow{3}{*}{\multicolumn{2}{|c|}{ Human }} & $\begin{array}{l}\text { No of } 10 \text { year old } \\
\text { children }\end{array}$ & \multirow[t]{2}{*}{$\begin{array}{l}\text { Proportion of } 10 \text { year olds in } \\
\text { school }\end{array}$} & \multirow[t]{2}{*}{ Range 0:100 } & \multirow[t]{2}{*}{0.3} & \multirow[t]{2}{*}{$\begin{array}{l}{[\text { Data Ib/Data I]* }} \\
100 * 1 * 0.3\end{array}$} \\
\hline & & $\begin{array}{l}\text { School attendance } \\
\text { among } 10 \text { year old } \\
\text { children }\end{array}$ & & & & \\
\hline & & $\begin{array}{l}\text { School attendance } \\
\text { among } 10 \text { years old } \\
\text { girls }\end{array}$ & $\begin{array}{l}\text { Proportion of } 10 \text { year old girls in } \\
\text { school }\end{array}$ & Range 0:100 & 0.3 & $\begin{array}{l}{[\text { Data J/Data I]* }} \\
100 * 1 * 0.3\end{array}$ \\
\hline \multirow{3}{*}{\multicolumn{2}{|c|}{ Human }} & $\begin{array}{l}\text { No of } 15 \text { year old } \\
\text { children }\end{array}$ & \multirow[t]{2}{*}{$\begin{array}{l}\text { Proportion of } 15 \text { year olds in } \\
\text { school }\end{array}$} & Range 0:100 & 0.3 & $\begin{array}{l}{[\text { Data L/Data K]* }} \\
100 * 1 * 0.3\end{array}$ \\
\hline & & $\begin{array}{l}\text { School attendance } \\
\text { among } 15 \text { year old } \\
\text { children }\end{array}$ & & Range 0:100 & 0.3 & $\begin{array}{l}{[\text { Data L/Data K] }]^{*}} \\
100 * 1 * 0.3\end{array}$ \\
\hline & & $\begin{array}{l}\text { School attendance } \\
\text { among } 15 \text { year old girls }\end{array}$ & $\begin{array}{l}\text { Proportion of } 15 \text { year old girls in } \\
\text { school }\end{array}$ & Range 0:100 & 0.3 & $\begin{array}{l}{\left[\text { Data M/DataK] }{ }^{*}\right.} \\
100 * 1 * 0.3\end{array}$ \\
\hline \multirow{2}{*}{\multicolumn{2}{|c|}{ Human }} & $\begin{array}{l}\text { No of children who } \\
\text { completed higher } \\
\text { secondary school }\end{array}$ & $\begin{array}{l}\% \text { of population completing } \\
\text { higher secondary school }\end{array}$ & Range 0:100 & 1.0 & $\begin{array}{l}{[\text { Data } \mathrm{Mb} / \mathrm{Data} \mathrm{A}] *} \\
100 * 1 * 1\end{array}$ \\
\hline & & $\begin{array}{l}\text { No of girls who } \\
\text { completed higher } \\
\text { secondary school }\end{array}$ & $\begin{array}{l}\% \text { of girls who completed higher } \\
\text { secondary school }\end{array}$ & Range 0:100 & 1.0 & $\begin{array}{l}{[\text { Data Mt/DataA }]^{*}} \\
100 * 1 * 1\end{array}$ \\
\hline \multicolumn{2}{|c|}{ Social } & $\begin{array}{l}\text { No of days of commu- } \\
\text { nity labor contirbuted } \\
(/ \mathrm{yr})^{8}\end{array}$ & $\begin{array}{l}\text { Community work Labor force / } \\
\text { capita }\end{array}$ & Range 0:20 & 2.0 & {$[\mathrm{Data} / \mathrm{A}] * 5 * 2$} \\
\hline \multirow{2}{*}{\multicolumn{2}{|c|}{$\begin{array}{l}\text { Elder } \\
\text { Committee }\end{array}$}} & No of member & \multirow[t]{2}{*}{ Gender ratio in elder committee } & \multirow[t]{2}{*}{ Range 0:50 } & \multirow[t]{2}{*}{0.2} & \multirow[t]{2}{*}{$\begin{array}{l}{[\text { Data } \mathrm{O} / \mathrm{DataN}] * 2} \\
* 0.2 * 100\end{array}$} \\
\hline & & No of females & & & & \\
\hline \multirow{10}{*}{$\begin{array}{l}. \frac{\pi}{0} \\
0 \\
\mathscr{n}\end{array}$} & \multirow{2}{*}{$\begin{array}{l}\text { Youth } \\
\text { Committee }\end{array}$} & No of members & \multirow[t]{2}{*}{ Gender ratio in Youth committee } & \multirow[t]{2}{*}{ Range 0:50 } & \multirow[t]{2}{*}{0.2} & \multirow{2}{*}{$\begin{array}{l}{[\text { Data } \mathrm{Q} / \text { DataP }] * 2 *} \\
0.2 * 100\end{array}$} \\
\hline & & No of females & & & & \\
\hline & \multirow{2}{*}{$\begin{array}{l}\text { Party } \\
\text { Committee }\end{array}$} & No of females & \multirow[t]{2}{*}{ Gender ratio in Party committee } & \multirow[t]{2}{*}{ Range 0:50 } & \multirow[t]{2}{*}{0.2} & \multirow{2}{*}{$\begin{array}{l}{[\text { DataS/DataR }] * 2 *} \\
0.2 * 100\end{array}$} \\
\hline & & No of members & & & & \\
\hline & \multirow{2}{*}{$\begin{array}{l}\text { LM Commit- } \\
\text { tee }\end{array}$} & No of females & \multirow[t]{2}{*}{ Gender ratio in LM committee } & \multirow[t]{2}{*}{ Range 0:50 } & 0.2 & [DataU/DataT]* \\
\hline & & No of members & & & & \\
\hline & H.VU & No of females & Gender ratio in $\mathrm{H} . \mathrm{VU}$ & Range 0:50 & 0.2 & {$[$ Data W/DataV]* } \\
\hline & Committee & No of members & & & & 100 \\
\hline & Leaders & No of females & Gender rate in Leader (Naibans) & Range 0:50 & 0.2 & {$[$ Data Y/Data X]*2* } \\
\hline & Committee & No of members & $\mathrm{col}$ & & & $0.2 * 100$ \\
\hline
\end{tabular}

7 Education data collected by Dafo during 2005 Census

${ }^{8}$ Work involving more than 10 people fo village purpose (e.g: road repairing, school buillding, etc) 
FIGURE 2 Livelihood status by village
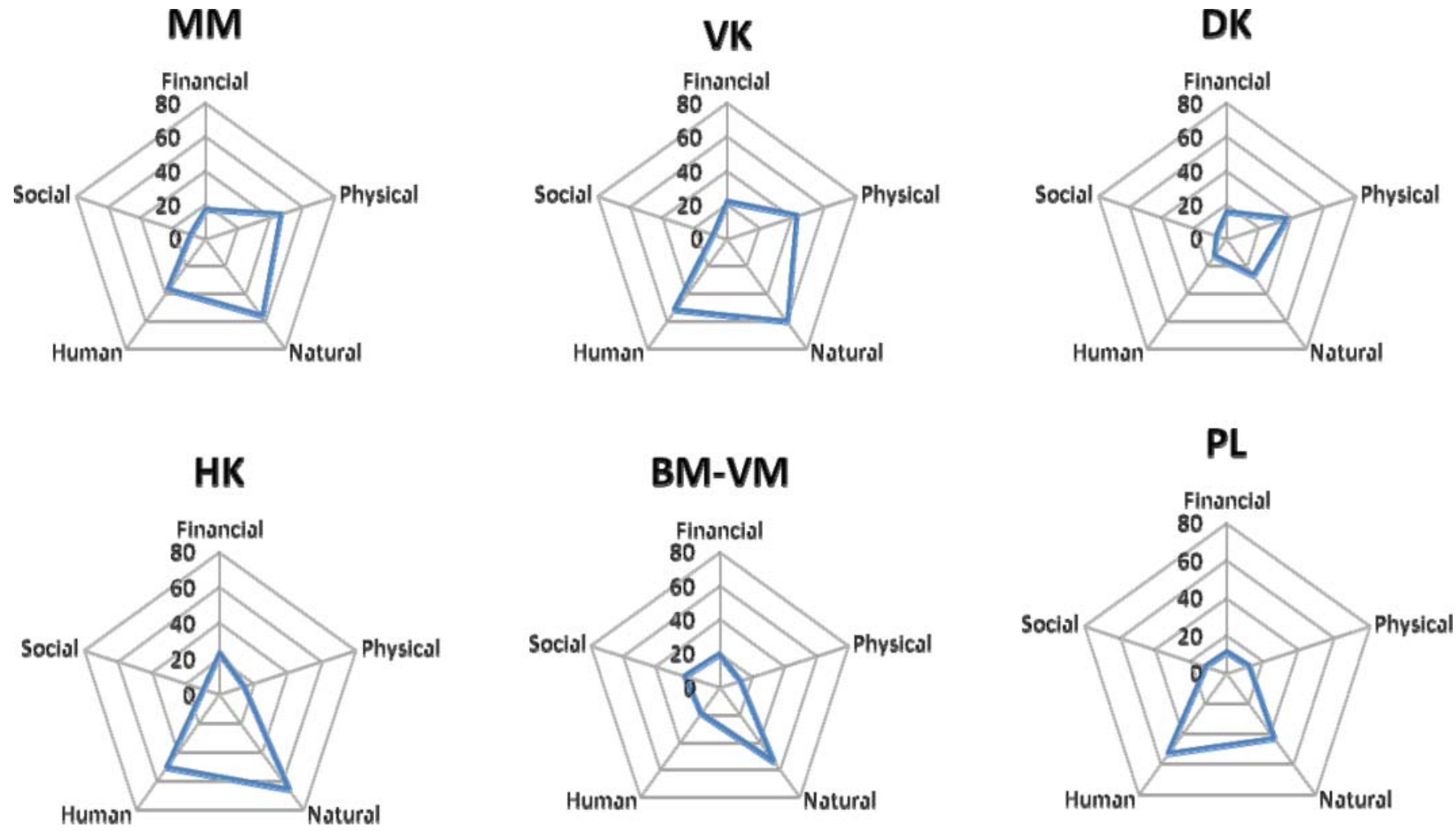

FIGURE 3 Comparing Villages by capital asset

\section{Financial}

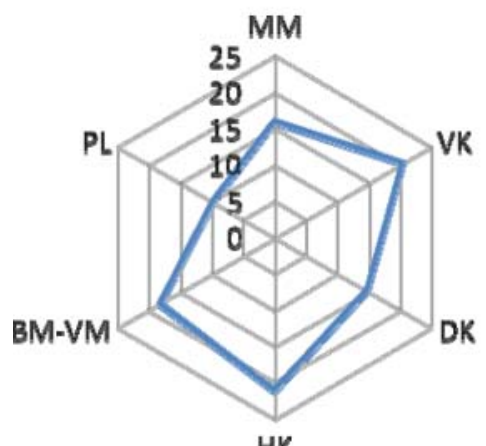

Physical

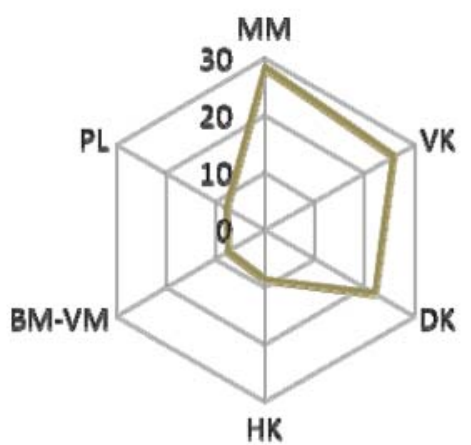

Natural

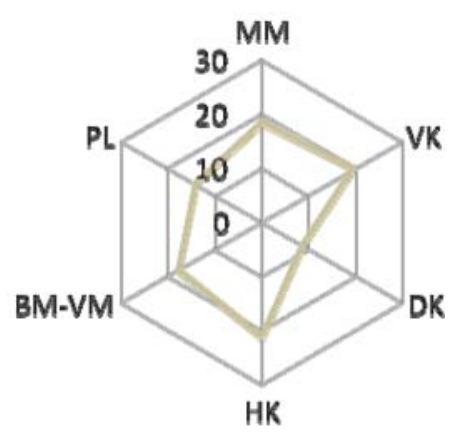

Human

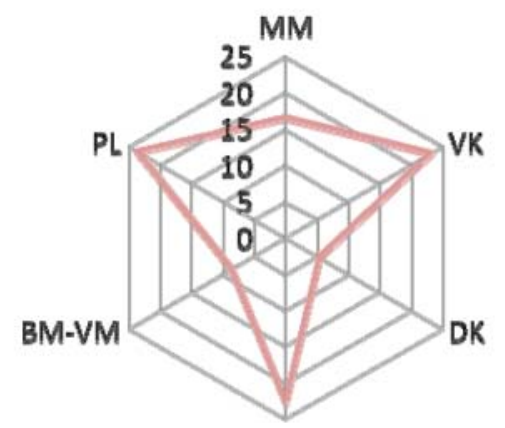

$\mathrm{HK}$
Social




The current tool has not yet been sufficiently tested nor proven its attractiveness to the key stakeholders. In practice, it reflects some aspects of livelihoods well, such as financial and physical capital, but other aspects are less well represented. Social capital was difficult to reflect in practical, easily measurable indicators. Likewise, we were unable to develop a suitable, broadly applicable indicator of the livelihood contribution of forest quality or quantity. We measured forest use using specially-collected data on NTFP harvest as a proxy, but this is still unsatisfactory as these indicators may not be broadly applicable beyond the study site.

Despite these shortcomings in the current application, the tool is effective as a way to focus attention on key aspects of rural development and as a way to inform and facilitate discussion and negotiation between communities, government, conservation and development organizations and others with interests and interventions that affect community development. Most of the indicators used in the trial are applicable widely in rural areas of the District, the Province and beyond, they are defined to be easily comparable, and the required data can be collected at low cost. It provided a good reflection of general livelihoods status at the village scale, broadly consistent with subjective ranking by village leaders and by local government officials. Inconsistencies between our ranking and the subjective rankings reflect different weights, and especially the higher weight given by local authorities to financial and physical capital. We argue that the tool promotes explicit examination of the criteria and weights and that using it will encourage valuable dialogue about livelihoods and local development.

Our projects made a high investment in activities to ascertain local values, expectations and aspirations because there were several objectives, including testing different participatory approaches. It is critical to engage local stakeholders, but it could be done at lower cost using one or two key approaches. It was important to engage District officials so that they were familiar with the ideas and felt involved in the design of the monitoring system.

Still, the tool was not adopted either by the District or by any ongoing projects in the area. This highlights a serious challenge faced by any effort to develop and implement tools of this sort. Implementation requires commitment and resources which are typically lacking in developing country government agencies. Moreover, government personnel often lack the incentive to utilize such an approach. Externally funded conservation and development projects, with explicit livelihoods objectives and intentions to engage stakeholders, are more likely in the short-term to value such an approach. A tool like the one developed here can help identify needs and expectations among intended project beneficiaries, and empower them to assess, analyze and provide feedback on project progress. It also offers useful monitoring information for project managers, a means to compare progress in different sites, and a credible source of information on project impact on local livelihoods, something that all donors want. In our case, the lone staff-person with an international NGO that was implementing a project in the area was involved in discussions and the design process, and was interested to use the tool. Unfortunately, that individual was replaced and the new person was quickly overwhelmed with their new duties and did not follow-up to use the monitoring tool.

Although it was not designed to track or attribute the effects of specific interventions, it could be adapted for that purpose in conjunction with a clear causal model that identifies the specific kinds of impacts intended. New initiatives, such as performance-based payments for ecosystem services (e.g. REDD), especially those with explicit livelihoods improvement objectives, could provide a good initial incentive for local communities to engage in livelihood monitoring at the same time they engage in biodiversity and carbon monitoring (Blom et al. 2010, Danielsen et al.. 2011). It is suggested that data for all variables should be collected annually by an individual or team in each village from available data and from interviews with key informants. Dedicated staff would be charged with collating and analyzing the data, and delivering copies of the data and livelihood monitoring outputs to village heads. The tool would become more valuable if more villages/districts adopt it and/or if it is used by externally-funded projects.

The most important aspect of this approach is that it provides information and an entry point for discussions among stakeholders (community members, community leaders, government officers, project managers, etc) about livelihoods status and change. It allows interested parties to know whether and how livelihoods are improving (or not) and so provides valuable feedback to guide the implementation and adaptation of projects and/or policies.

\section{ACKNOWLEDGEMENTS}

We are grateful to the people in the research villages who warmly welcomed us. We thank colleagues in the Landscape Mosaics project (funded by the Swiss Agency for Development and Cooperation), the District Agricultural and Forestry Office, and The National Agriculture and Forestry Research Institute for their valuable collaboration, as well as colleagues from the Comprehensive Analysis of the Trajectories of Changes (Catch-Up) Program and the Institut de Recherche pour le Développement (IRD, France). The research was supported through the project "Developing more Effective Methods for Assessing Conservation and Livelihoods Outcomes in Forest Landscapes" funded by Canadian International Development Agency via the Canada-CGIAR Linkage Fund and the Canadian Social Sciences and Humanities Research Council.

\section{REFERENCES}

ALDRICH, M and SAYER, J. 2007. In Practice: Landscape Outcomes Assessment Methodology "LOAM". World Wildlife Fund Forests for Life Program.

BECKLEY, T. 2000. Sustainability for whom? Social indicators for forest-dependent communities in canada. Edmonton, Alberta: Sustainable Forest Management Network University of Alberta. 
BECKLEY, T., PARKINS, J.R. and STEDMAN, R.C. 2002. Indicators of forest-dependent community sustainability: The evolution of research. The Forestry Chronicle 78(5): 626-636.

BELCHER, B. and ROBERTS, M. (in press). Assessing local perspectives on environment and development in Lao PDR using participatory photography. Forests, Trees and Livelihoods.

BEBBINGTON, A. 1999. Capitals and capabilities: a framework for analyzing peasant viability, rural livelihoods and poverty. World Development 27:2021-2044.

BLOM, B., SUNDERLAND T., and MURDIYARSO. 2010. Getting REDD to work locally: lessons learned from integrated conservation and development projects. Environmental Science \& Policy 13:164-172.

BOISSIÈRE, M., BASTIDE, F., BASUKI, I., PFUND, J.L. and BOUCARD, A. (in press). Can we make participatory NTFP monitoring work? Draft.

BOND, R., KAPONDAMGAGA, P.H., MWENEBANDA, B., YADAV, R.P.S. and RIZVI, A. 2005. Monitoring the livelihood platform: Reflections on the operation of the L.A.S.T. method from India and Malawi. Livelihood Summit, Udaipur, Rajasthan, India. 26.

BOND, R., and MUKHERJEE, N. 2002. Livelihood asset status tracking: An impact monitoring tool? Journal of International Development 14: 805-815.

BOUCARD, A., BOISSIÈRE, M., CASTELLA, J.C., BASUKI, I., PONKPHADY, S., MOUAXENG-CHA, K., THEPHAVANH, M. and VONGMANY, O. 2010. Methodology of design of a participatory monitoring system for clusters of villages in Lao P.D.R. Technical Report, CIFOR and NAFRI.

BOURGOIN, J., CASTELLA, J.C., PULLAR, D., LESTRELIN, G., and BOUAHOM B. (2012). Toward a land zoning negotiation support platform: "Tips and tricks" for participatory land use planning in Laos. Landscape and Urban Planning 104: 270-278. http://dx.doi.org/10.1016/ j.landurbplan.2011.11.008

BROOKS, J.S, FRANZEN, M.A., HOLMES, C.M., GROTE, M.N. and BORGERHOFF MULDER, M. 2006. Testing hypotheses for the success of different conservation strategies. World Development 27: 2021-2044.

BURLEY, J. 2001. International initiatives for the sustainable management of forests. In SHEPPARD, S.R.J. and HARSHAW, D.H.W. (Eds.), Forests and Landscapes: Linking Ecology, Sustainability and Aesthetics. CABI Publishing, Wallingford, Oxon: 95-102.

CARNEY, D., DRINKWATER, M., RUSINOW, T., NEEFJES, K., WANMALI, S. and SINGH, N. 1999. Livelihoods approaches compared. A brief comparison of the livelihoods approaches of the UK department for international development (DFID), CARE, Oxfam and the United Nations development programme (UNDP) CARE, Oxfam, UNDP.

CASTELLA, J.C., THEPHAVANH, M., VONGKHAMSAO, V., MOUAXENG-CHA, K., PHONPHAKDY, S., FITRIANA, Y.R., KONGAY, K., PHAIPASITH, S., FERRAND, J., MANIVANH, V. and PFUND, J.L. 2011. Evolving relations between agriculture and forest in Viengkham District, Luang Prabang Province. Lao Journal of Agriculture and Forestry 23: 61-89.

COLFER, C. and PFUND, J.L. (eds) 2010. Collaborative governance of tropical landscapes. Earthscan, London.

DANIELSEN F, JENSEN, A.E., ALVIOLA, P.A., BALETE, D.S., MENDOZA, M., TAGTAG, A., CUSTODIO, C., EENGHOFF, M. 2005. Does monitoring matter? A quantitative assessment of management decisions from locally-based monitoring of protected areas. Biodiversity and Conservation, 14: 2633-2652.

DANIELSEN, F., SKUTSCH, M., BURGESS, N.D., JENSEN, P.M., ANDRIANANDRASANA, H., KARKY, B., LEWIS, R., LOVETT, J.C., MASSAO, J., NGAGA, Y., PHARTIYAL, P., POULSEN, M.K., SINGH, S.P., SOLIS, S., SØRENSEN, M., TEWARI, A., YOUNG R. and ZAHABU, D.E. 2011. At the heart of REDD: a role for local people in monitoring forests? Conservation Letters 4: 158-167.

ELLIS, F. 2000. Rural Livelihoods and Diversity in Developing Countries. New York: Oxford University Press.

ENDAMANA, D., BOEDHIHARTONO, A.K, BOKOTO, B., DEFO, L., EYEBE, A., NDIKUMAGENGE, C., NZOOH, Z., RUIZ-PEREZ, M., AND SAYER, J.A. 2010. A framework for assessing conservation and development in a Congo Basin Forest. Tropical Conservation Science 3(3): 262-281.

EVANS, K., and GUARIGUATA, M. 2008. Participatory monitoring in tropical forest management: A review of tools, concepts and lessons learned. Bogor, Indonesia: Center for International Forestry Research (CIFOR).

FRASER, E.D.G., DOUGILL, A.J., MABEE, W.E., REED, M. and MCALPINE, P. 2006. Bottom up and top down: Analysis of participatory processes for sustainability indicator identification as a pathway to community empowerment and sustainable environmental management. Journal of Environmental Management 78(2): 114-127.

FITRIANA, Y.R. 2008. Landscape and Farming System in Transition: Case Study in Viengkham District, Luang Prabang Province, Lao PDR. Agronomy and Agro-Food Program, Institut des Regions Chaudes-Supagro, Montpellier, France.

GOL. 2003. National Growth and Poverty Eradication Strategy. Government of the Lao People's Democratic Republic, Vientiane.

HARSHAW, H.W., SHEPPARD, S.R.J. and LEWIS, J.L. 2007. A review and synthesis of social indicators for sustainable forest management No. 8). Kamloops: FORREX Forest Research Extension Society.

HETT C., CASTELLA, J.C., HEINIMANN, A., MESSERLI, P. and PFUND, J.L. 2011. A landscape mosaic approach for characterizing swidden systems from a REDD+ perspective. Applied Geography 32: 608-618.

JOHNSON, A. 2011. Landscape Summary for the Nam Et-Phou Louey National Protected Area, Lao PDR. In Sunderland T. et al. (eds) Conservation and Development in Lower Mekong. 
LEE, K.N. 1993. Compass and Gyroscope: Integrating Science and Politics for the Environment. Washington, D.C.: Island Press.

MAF-NLMA. 2009 Manual on participatory agriculture and forest land use planning at village and village cluster levels. Ministry of Agriculture and Forestry and National Land Management Authority, Vientiane.

NATCHER, D.C. and HICKEY, C.G. 2002. A criteria and indicators approach. Edmonton, Alberta: Sustainable Forest Management Network.

PFUND, J.L, WATTS, J.D., BOISSIÈRE, M., BOUCARD, A., BULLOCK, R.M., EKADINATA, A., DEWI, S., FEINTRENIE, L., LEVANG, P., RANTALA, S., SHEIL, D., SUNDERLAND, T. and URECH, Z. 2011. Understanding and Integrating Local Perceptions of Trees and Forests into Incentives for Sustainable Landscape Management. Environmental Management 48(2): 334349.

POULSEN M.K. and LUANGLATH, K. 2005. Projects come, projects go: lessons from participatory monitoring in southern Laos. Biodiversity and Conservation 14: 2591-2610.

SAYER, J., CAMPBELL, B., PETHERAM, L., ALDRICH, M., RUIZ PEREZ, M. and ENDAMANA, D. 2006. Assessing environment and development outcomes in conservation landscapes. Biodiversity and Conservation 16: 2677-2694.

SEN, A. 1999. Development as Freedom. Oxford University Press, Oxford U.K.

SENGE, P.M. 2006. The Fifth Discipline: The Art and Practice of the Learning Organization. New York: Currency Doubleday. ISBN978-0385260954.
SHEIL D, PURI, R.K., BASUKI I., VAN HEIST, M., WAN, M., LISWANTI, N., RUKMIYATI, I., SARDJONO, M. A., SAMSOEDIN, I., SIDIYASA, K., CHRISANDINI, PERMANA, E., ANGI, E.M., GATZWEILER, F., JOHNSON, B. and WIJAYA, A. 2002. Exploring biological diversity, environment and local people's perspectives in forest landscapes Methods for a multidisciplinary landscape assessment. Center for International Forestry Research, Bogor.

SHERRY, E., HALSETH, R., FONDAHL, G., KARJALA M. and LEON, B. 2005. Local-level criteria and indicators: An aboriginal perspective on sustainable forest management. Forestry 78(5): 513-539.

SINGH S. 2008. Social challenges for integrating conservation and development: the case of wildlife use in Laos. Society and Natural Resources 21: 952-955.

STRINGER, L.C., DOUGILL, A.J., FRASER, E., HUBACEK, K., PRELL, C. and Reed, M.S. 2006. Unpacking "participation" in the adaptive management of social-ecological systems: a critical review. Ecology and Society 11(2): 39. [online] URL: ttp://www.ecologyandsociety.org/vol11/iss2/art39/

WATTS, J.D., VIHEMÄKI, H., BOISSIÈRE, M. and RANTALA, S. 2011. Information flows, decision making and social acceptability in displacement processes, in Collaborative Governance of Tropical Landscapes PIERCE COLFER, C.J. and PFUND, J.L. (eds), Earthscan, London, pp 79-106.

WELLS, M.P., and MCSHANE, T.O. 2004. Integrating protected area management with local needs and aspirations. AMBIO: A Journal of the Human Environment 33(8): 513-519. 